According to the method of sensomotor kinesiotherapy, exercises for physical education are classified according to the target orientation: exercises for optimization of the tonic component of motility in a passive way; exercises for the development of visual-motor coordination; exercises to integrate early postures and movements into more complex coordination; exercises for the development of the cognitive sphere.

Consequences of the influence of conducting classes according to the proposed method: reduction of functional hypotension, increase of diversity of activity, development of communication, development of general motor skills, development of fine motor skills, development of great motor skills and coordination of movements, perception of speech, improvement of work of the apparatus of articulation, self-care.

Thus, the results of the use of the sensomotor kinesitherapy technique in physical education classes demonstrate that it is an effective tool for improving the psychomotor functions of children aged 5-6 years with Down syndrome [1].

Children became better able to navigate space and to understand their own bodies, to respond more quickly to environmental changes and adapt to them. Their cognitive level increased, motor abilities improved (children became more motor-agile, movements became clearer, components of impaired movement coordination became smaller). With children it became easy to negotiate, to carry out more complex joint activity. The time of completion of any task (both physical and mental) and the degree of active participation in it have increased several times in comparison with the initial indicators.

\title{
References:
}

1. Dmitriieva, N. S. (2019). Vplyv zaniat iz fizychnoho vykhovannia za metodykoiu sensomotornoi kinesioterapii na psykhomotornyi rozvytok ditey 5-6 rokiv sz syndromom Dauna [Influence of physical education sensomotor kineseotherapy method for psychomotor development of children of 5-6 years with Down syndrome]. Innovative pedagogy, vol. 2, no. 13, pp. 111-116.

\section{PECULIARITIES OF TEACHING LATIN PHONETICS IN THE FRAMEWORK OF E-LEARNING: STRATEGIES AND PRACTICAL TIPS}

\begin{abstract}
Alla Kulichenko ${ }^{1}$ Yuriy Polyezhayev ${ }^{2}$
\end{abstract}

DOI: https://doi.org/10.30525/978-9934-588-11-2_51

It is believed that Latin is a dead language because there are no native speakers and the language remains unchanged. That's why proper reproduction of letter-phoneme matching and other phonetic peculiarities are impossible. However, today Latin is a

\footnotetext{
${ }^{1}$ Zaporizhzhia State Medical University, Ukraine

${ }^{2}$ National University «Zaporizhzhia Polytechnic», Ukraine 
basis of scientific terminology, international nomenclatures and is widely used in medicine, pharmacy, law, the Catholic Church, etc.

M. Covington states, "The ancient Roman pronunciation wasn't accurately reconstructed until about 1900. Before that, scholars in every European country pronounced Latin as if it were their own language. With English, this gave particularly comical results because English pronunciation had undergone drastic changes at the end of the Middle Ages» [1].

There are four ways of Latin pronunciation: reconstructed ancient Roman; northern Continental Europe; «Church Latin» in Italy; «English method». Speaking about any terminology and Latin as its basis, M. Covington recommends using «the northern Continental pronunciation for unfamiliar scientific terms, since it resembles many modern languages and is, in fact, the pronunciation used by Copernicus, Kepler, Linnaeus, and other scientific pioneers» [1]. Ukrainian researches R. Dombrovskyi and N. Revak add that «modern Latin reading norms appeared in European countries in $\mathrm{XIX}^{\text {th }}$ century, but such a pronunciation is only relative and implies a degree of approximation to the real pronunciation of the Romans. The reconstruction of the classical pronunciation requires very careful preparatory work, besides, the peculiarities of Latin pronunciation are reproduced only within the conditions offered by the native language sound system» $[2$, p. 214].

As O. Nybakken considers, «Not all the difficulties encountered in the study of a science are inherent in the subject matter; many are due to the terminology used. In some areas of science, the student may spend a year or more in becoming acquainted with the terminology» [4, p. 1]. Traditionally, in Ukraine, there are two semesters or one semester (usually the first year of studies) dedicated to Latin and its terminology at the non-classical higher educational establishments (medical, pharmaceutical, law, polytechnic, theological, etc.). During the academic year students learn peculiarities of Latin phonetics, grammar, syntax, and terminology according to the chosen field of science. In this research, we will highlight some strategies and practical tips for teaching Latin phonetics in the framework of e-learning.

As a rule, the academic staff explains Latin reading and stress rules in the form of a semi lecture using a blackboard, tables, and textbooks. However, today, in the era of e-learning, the mentioned way of teaching loses its positions because students wait for interesting and interactive methods of teaching more and more often.

According to a guide for designing and developing e-learning courses «E-learning methodologies», «e-learning is the use of computer and Internet technologies to deliver a broad array of solutions to enable learning and improve performance» [3, p. 3].

The main advantage of e-learning is to involve as many students as possible, especially when they

- geographically dispersed with limited time and/or resources to travel;

- busy with work or family commitments which do not allow them to attend courses on specific dates with a fixed schedule;

- located in conflict and post-conflict areas and restricted in their mobility because of security reasons; 
- limited from participating in classroom sessions because of cultural or religious beliefs;

- facing difficulties with real-time communication (e.g. foreign language students or very shy students) [3, p. 9].

We assume teaching Latin phonetics with the help of e-learning as one of the strategies during the Latin lessons. Thus, there is a need to use simple learning resources and interactive e-lessons as types of e-learning content.

Simple learning resources are uninteractive ones, because students can only read or watch them, and can be represented with

- documents containing all the information concerning reading and stress rules in Latin;

- flashcards with Latin alphabet, Latin letters that correspond to certain phonemes, words divided into syllables (that are usually counted from the end to the beginning of any word), stressed and unstressed suffixes with examples, etc.;

- PowerPoint presentations with Latin reading and stress rules;

- videos with phonetic content. Academic staff can find it either on YouTube or on specialized websites. E.g.: the Latin alphabet. The pronunciation of vowels, diphthongs, consonants, and Greek letter combinations. https:/www.youtube.com/ watch? $\mathrm{v}=\mathrm{c} 65 \mathrm{HZp} 6 \mathrm{hl} 3 \mathrm{Q}$ - for Ukrainian students; the Latin alphabet - vowel pronunciation https://www.youtube.com/watch? $\mathrm{v}=\mathrm{LwtgvwJljto}$ - for foreign students with the English medium of instruction. Moreover, one can actually make a video;

- audio files with phonetic content, e.g. Latin aphorisms or proverbs with certain phonetic peculiarities can be recorded on a CD or DVD, flash device. Students can listen to them several times and repeat them.

The most common approach for self-study e-learning is Web-based training consisting of a set of interactive e-lessons. An e-lesson is a linear sequence of screens which can include text, graphics, animations, audio, video, and interactivity in the form of questions and feedback. E-lessons can also include recommended reading and links to online resources, as well as additional information on specific topics [3, p. 11]. For example, there is a possibility to create a course on Latin phonetics on the edX platform (https://www.edx.org/). The course may be a supplement to the information given during a lesson.

Moreover, if students have doubts concerning reading terms, they can use such web page as http://graecolatini.bsu.by/htm-different/latin-translit.htm. The matter is that this page provides users with main rules concerning transliteration (transcription) of Latin words, prepared by an associate professor K.Tananushko, and an online program that transliterates (transcripts) a Latin word due to the settings «Tradition», «Classic» or «Medicine».

So, today Latin is a language of scientific terminology despite it is not on the rise as English. That's why one should teach Latin phonetics properly. Note that Latin phonetics is introduced to Ukrainian students within the mother tongue. It means that the Latin letters are pronounced as close to the Ukrainian phonemes as possible. 
Conventional methods of teaching are giving way to e-learning that is regarded as the integration of electronic technologies within learning process both in a classroom and outside it. Thus, simple learning resources and interactive e-lessons dedicated to the Latin phonetics can help students acquire better phonetic competence and master it.

\section{References:}

1. Covington, M. A. (2010). Latin Pronunciation Demystified. Retrieved from: http://www.covingtoninnovations.com/mc/latinpro.pdf (accessed 10 September 2019).

2. Dombrovskyi, R., \& Revak, N. (2012). Teoretychni zasady navchannia latynskoi vymovy [The theoretical principles of teaching Latin pronunciation]. Inozemna Filologia, no. 124, pp. 213-218.

3. Ghirardini, B. (2011). E-learning methodologies. A guide for designing and developing elearning courses, Rome: FAO. Retrieved from: http://www.fao.org/3/i2516e/i2516e.pdf (accessed 15 September 2019).

4. Nybakken, O. E. (1979). Greek and Latin in Scientific Terminology, The Iowa: Iowa State University Press.

\section{THE FEATURES OF TOLERANCE IN PARENT-CHILD RELATIONSHIP}

\section{Hanna Liulka ${ }^{1}$}

DOI: https://doi.org/10.30525/978-9934-588-11-2_52

At all times, since antiquity, the problems of the family have concerned leading scholars, artists and philosophers. The family as a living system changes not only under the influence of socio-economic conditions, but also due to internal processes of development. At the present stage of society's development, new problems that arise cause the distabilization of vital functions of the family and reduce its adaptation ability to new conditions.

One of the challenges of family education is the violation of parental tolerance. The mental and physical health of the person is closely connected with the parentchild relationship. Family conflicts not only disorganize, destroy family unity, but also serve as the basis for the accumulation of the deviant behavior of the child. By virtue of the children's rights discrimination, they lose own fundamental freedoms and individuality, as a result they have an emotional disturbance, feelings of constant anxiety and deviations from the norm in behavior of different characters. Unfortunately, adults often do not notice the prospects of parent-child relationship complexification, do not assess the degree of their influence on personal formation and development of their children.

Family - the institute of education, in which the foundations of human morality are laid, the attitudes towards the surrounding are formed, and the evaluations of their actions are adjusted. Naturally, school has considerable educational potential, but

\footnotetext{
${ }^{1}$ Poltava V. G. Korolenko National Pedagogical University, Ukraine
} 